49) W. Marasich, J. Am. Oil Chemists' Soc., 34, 220 (1957)

50）石井，本田，醱酵技術，29，222-5 (1951)

51) M. Antila, C.A., 48, 4141 (1954)

52) H. Schmidt, Fette u. Seifen, 58, 821 (1956)

53) H. Schmidt, Neue Verpackung, 10, (1) 32-3
(1957)

54) G. Wode et al., J. Am. Oil Chemists' Soc., 34, 606 (1957)

55) J.B. Brown, J. Am. Oil Chemists' Soc., 33, 98-102 (1956)

\title{
ビタミンと抗酸化剤
}

\author{
勝 井五一 郎*
}

\section{Vitamins and Antioxidants}

\section{Goichirō KATSUI}

油脂は空気中の酸素により容易に酸敗するが，ビタミ ン $\mathrm{A}$, カロチン, ビタミン $\mathrm{D}, \mathrm{E}, \mathrm{F}$ なども同様に空気中 の酸素により常温でたやすく酸化され, その生理的効果 を失うばかりでなく，ときには酸化により生じた物質が 有毒で生体に強い害を及ぼすことがあるので，これらの 酸化防止については留意され, 酸化防止剤あるいは防止 法が研究され，また利用されてきた。

\section{I. ビタミン $\mathbf{A}$}

肝油中には天然に抗酸化性物質が存在しているためビ タミンA てビタミン $\mathrm{A}$ の濃縮を行うとき，法の括のの抽留極大** が異なるので得られたビタミン $\mathrm{A} の$ 濃縮油の安定度は原 油より劣る。また製剤化するときは当然空気との接触の 機会が多くビタミンAの安定度は低下する。それで酸化 を防止するために資料を容器に充満したり, 不活性ガス 充てんを行うとか, あるいはシャ(遮)光などの方法がと られてきた。しかしビタミンAの酸化機構が明らかにな るに及んで抗酸化剤が取り上げられ，今日ではビタミン A製剤には必ず何らかの抗酸化剂が添加されている状態 である。

\section{1. ビタミン A 酸化防止剤の効力試験}

抗酸化剂の効果の判定方法は一定でなく, 各人各様の 方法を採用している。これは同一の抗酸化剤でも試験対 照が異なるとその効果に差がある場合がしばしばあるた めである。たとえばクェルセチンは豚脂, 綿実油に対し 有効な抗酸化剂とされているが1), ビタミンA

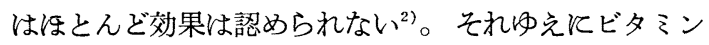
A 江用いる抗酸化剂は一応ビタミンAを用いてきめる必

*エーザイ株式会社研究部（東京都文京区竹早町） Research Laboratories of Eisai Co. Ltd.

** 解析蒸留に括いて留出油中の目的物の濃度が極大に 達する温度。
要がある。一般にビタミンAに対し行われている試験方 法にはつぎのあのがある。

a ) ビタミン $\mathrm{A}$ 油に抗酸化剂を添加して測定する方法 ${ }^{3)}$ 徍約 $3 \mathrm{~cm}$ の小型シャーレに抗酸化剂を含有していな いビタミンA油を正確に $1 \mathrm{~g}$ ひょう(科)取し, これに試 料を $0.1 \%$ 添加してよく混和する。別に比較用としてビ タミン $\mathrm{A}$ 油のみのものおよび標準抗酸化刘を加えたもの を作り，これらの小型シャーレをフタ付の大型シャーレ に拉さめ $30 \sim 40^{\circ} \mathrm{C}$ の恒温器中に招き，ときどきビタる ンA量を三塩化アンチモン法で測定して次式によって抗 酸化力を算出する。著者はこの方法を用いて抗酸化剤を 選択してきた。

$$
\text { 抗酸化力 }=\frac{\text { 試料を添加したるののビタミン }}{\mathrm{A} \text { 量が } 50 \% \text { となる日数 }}
$$

この場合標準抗酸化剤を用いるのはビタミンA油の品 質の判定と, 数次にわたって行った実験成績の比較対照 を行うためである。

b) カロチンまたはビタミン $\mathrm{A}$ を浴媒で希㗭し，こ れに酸化防止刜を添加して測定する方法

Bickoff $ら^{4)}$ はカロチンを鉣物油, 豚脂, ヤシ油など で希釈し，これに試料を加えカロチン量が $20 \%$ 失われ る時間を求めて抗酸化力を測定しているが, 表-1のよう に希釈に用いる溶媒によってその成績に大きな変化があ

表-1 カロチンの $20 \%$ が失われる時間 (hr)

\begin{tabular}{|c|c|c|c|}
\hline 試 料 溶 媒 & 鉱 油 & 豚 脂 & ヤシ油 \\
\hline 無 添 加 & 2 & 3.5 & 0.5 \\
\hline ピロガロール & 155 & 136 & 74 \\
\hline 4-エチル-PG & 185 & 75 & 97 \\
\hline 2,6-ジエチル-PG & 162 & 39 & 75 \\
\hline 4-ベンゾイル-PG & 240 & 40 & 5 \\
\hline
\end{tabular}

$\mathrm{PG}:$ 没食子酸プロピル 
るので，この点注意を要する。

c) 口紙法

桜井 ${ }^{5}$ らは肝油を精製乾燥ベンゼンに溶解し, これに 試料を添加したのち, 口紙片に任意の個数を滴下しベン ゼンを蒸発したのち $40^{\circ} \mathrm{C}$ に保存し，ときどきビタミン $\mathrm{A}$ 測定してビタミン $\mathrm{A} か ゙$ 消失する時間を求め無添加の ものと比較して抗酸化力を算出しているが，この方法は 测定が短時間で終る利点がある一面, 抗酸化力が従来 a）により測定した值と一致しないことがときとしてあ ることが欠点である。これはベンゼンに溶解した肝油と 試料の口紙上での拡散速度が異なるため滴下した中心部 と周辺部でビタミン $\mathrm{A}$ の消失時間に差があり判定が困難 なのが原因である。この点とついては小川ら゙ 試料をベンゼンに溶解し, これに一定面積のロ紙を浸セ キしロ紙全面に肝油と試料を同一濃度に付着させた上で 武験するように改良している。

d) 固形物で希彩したビタミンAを用い测定する方法 河合ら『はビタミンA油をデンプンで希釈し，これに 試料を昉 $30^{\circ} \mathrm{C}$ に保存してときどきビタミン $\mathrm{A}$ 量を 測定し, ビタミンAが50\%減少する時間を求めて抗酸化 力を算出している。著者はこの方法について検討したが 希彩に用いる基材によってビタミン $\mathrm{A}$ の酸化に羊速があ り,ときとして従来の a)の方法で得た成績と一致しない ことが缌められた ${ }^{8}$ 。したがってこの点十分注意を要す る。

\section{2. 抗酸化剤}

ビタミンAに対しては戦後 NDGA が用いられたが, 高価であるため最近は BHA, BHT などがもっぱら使用 されており，またこれらに没食子酸エステル類が混用さ れ, あるいはこれにクエン酸, アスコルビン酸などが添 加されて使用されている。つぎにビタミン $\mathrm{A}$ と関係の深 い抗酸化剂ならび著者の合成した抗酸化剤のうち,一, 二の強力なものとついて記す。

a) NDGA (nordihydroguaiaretic acid)

NDGA（I） はアメリカ西南部に育成する creosote bush から抽出されたすのでつぎの構造を有し抗酸化力 はきわめて強い。

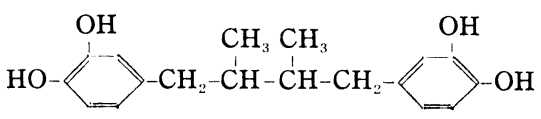

著者はこれて類するヒドロキノン-NDGA (1,4-ビス(2,5-ジオキシフェニル) $-2,3-$ - ジチルブタン) (II) 拉<smiles>CC(Cc1cc(O)ccc1O)C(C)Cc1cc(O)ncc1O</smiles>

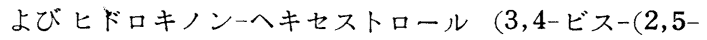
ジオキシフェニル)-ヘキサン)(III) を合成したが，これ
らは NDGA よりも強力な抗酸化力を示した。<smiles>CCC(c1cc(O)ccc1O)C(CC)c1cc(O)ccc1O</smiles>

しかしこれと同じような構造をもつレゾルシン-NDG A(IV) やp-クレゾール-NDGA (V) は NDGA に比し 著しく抗酸化力の少ることを涩めた9)。<smiles>Cc1ccc(O)c(CC(C)C(C)Cc2cc(O)ccc2O)c1CC(C)C(C)Cc1ccc(O)cc1O</smiles>

これらの抗酸化力を比較すると表-2のと括りである。

b) BHA (butylhydroxyanisol)

BHA は NDGA と異なり合成品で抗酸化剂としてき わめてすぐれて拉り，2-tert-ブチル-4-オキシアニソー ル（I）と 3-tert-ブチル-4-オキシアニソール（II）の 混合物で（II）の方が抗酸化力がはるかにすぐれてい る。一般には（II）を90\%以上含むるのが使用されてい る。<smiles>COc1ccc(O)cc1C(C)(C)C</smiles>

( I )<smiles>COc1ccc(O)c(C(C)(C)C)c1</smiles>

(II) c) BHT (di-tert-butylhydroxytoluene)

BHT もきわめて強い抗酸化剤で価格す低廉であるの で最近次第に利用されてきた。<smiles>Cc1cc(C(C)(C)C)c(O)c(C(C)(C)C)c1</smiles>

ただしこのものは酸化が進むと強い黄色着色する欠 点がある。

d) Antioxidant 2246 (2,2'-ジオキシー3, 3'-ジ-tert ブチル-5, 5'-ジメチルジフェニルメタン)

この物質は American Cyanamide Co. から発売され たもので, 抗酸化力は NDGA に勝るとも劣らない ${ }^{10)}$ また毒性も NDGA より弱い゙11。<smiles>Cc1cc(Cc2cc(C)cc(C(C)(C)C)c2O)c(O)c(C(C)(C)C)c1</smiles>

e ）没食子酸エステル 
表-2 NDGA および関連化含物の抗酸化力 表中の数值はAの $\mathrm{mg} \%$ ，すなわち試料 $100 \mathrm{~g}$ 中の $\mathrm{A} の \mathrm{mg}$ 数をふす。

\begin{tabular}{|c|c|c|c|c|c|c|c|c|c|c|c|}
\hline 試 料 試 験 日 数 & 0 & 5 & 10 & 12 & 15 & 20 & 25 & 30 & 35 & 40 & 45 \\
\hline ヒドロキノン-NDGA & 1560 & 1560 & 1560 & 1560 & 1560 & 1320 & 1120 & 1000 & 840 & 560 & 500 \\
\hline ヒドロキノンーヘキセストロール & 1560 & 1560 & 1560 & 1560 & 1560 & 1320 & 1120 & 1000 & 840 & 560 & 500 \\
\hline レゾルシン-NDGA & 1560 & 1560 & 1360 & 1200 & 900 & 300 & & & & & \\
\hline$p-$ タレゾール-NDGA & 1560 & 1560 & 160 & & & & & & & & \\
\hline NDGA & 1560 & 1560 & 1560 & 1560 & 1440 & 1200 & 840 & 580 & 460 & 340 & \\
\hline 無＼cjkstart添 & 1560 & 1560 & 120 & & & & & & & & \\
\hline
\end{tabular}

没食子酸エステルとして用いられているものには没食 子酸プロピル,没食子酸イソアミル,没食子酸オクチル, 没食子酸ドデシルなどがある。これらはいずれも強い抗 酸化性を示すが, 微量の鉄または鉄塩の存在によりそれ 自身変色し，製品の色調を害する欠点をるっている。

f） トコフェロール

植物油中には広くトコフェロールが分布しており, 酸 化防止の役割を果している。トコフェロールには $\alpha, \beta$, $\gamma, \delta$ などあり, その生理的効果 (抗不妊性効果) は $\alpha$ 型が最も強くその比は $100: 30: 20: 1$ であるといわれ

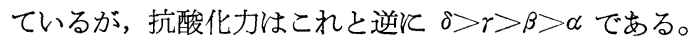

トコフェロールの抗酸化力は先に記した各種の抗酸化 剂に比し劣るが, 添加物を着色しない点, 毒性のほとん ぞない点に利点があるので強化食品や着色を特にきらう 製剂に利用されている。また最近ビタミンA濃縮油に 1 \%以上の高濃度飞添加すると強い抗酸化力を示し誘導期 間も他のものより長い長所が見出され利用されている。

g）その他の抗酸化剂

クェルセチン, ジヒドロクェルセチンはほとんど抗酸 化力をあたないが $3^{\prime}$-アミノ-4'-オキシフラボノールが わずか抗酸化力をもち ${ }^{12)}, \mathrm{K}_{3}$ は抗酸化力が注とんど ないが $\mathrm{K}_{5}$ は相当強力であり ${ }^{13)}$, ゴマ油中のセザモール， 綿実油中のゴシポールも強い抗酸化力を示すが，これら はビタミン $\mathrm{A} の$ 酸化防止剤として一般には使用されてい ない。

\section{3. 抗酸化剤のビタミン $\mathbf{B}_{1}$ 分解作用}

耐熱性ビタミン $\mathrm{B}_{1}$ 分解因子の作用を有しているもの にフラボノイド化合物があり, その側鎖の 3,4 位に水 酸基を置換したものが最もビタミン $\mathrm{B}_{1}$ の分解能が大で， 天然からはクェルセチン, イソクェルセチンを得たと長

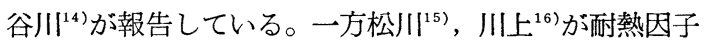
のモデルとしてフェノール類に着目し, 一価フェノール は分解能を有しないが， 0 -招よび $p$-位水酸基を有す る二価フェノールが著しい分解能を示すことを明らかに した。これから判断するとフェノール系抗酸化剤は当然 ビタミン $B_{1}$ 分解を行うことが推定される。実際 NDGA, ヒドロキノン-NDGA，ヒドロキノンーヘキセストロール， イソアミルヒドロキノン, ヒドロキノンなど構造の近い
ものとついて $\mathrm{B}_{1}$ 分解能を試験 したところ ${ }^{1 i}$, 表-3の と招り NDGA, ヒドロキノン-NDGA, ヒドロキノンーヘ キセストロール，ヒドロキノンは等モルではほぼ同一の ビタミン $\mathrm{B}_{1}$ 分解能をもち, イソアミルヒドロキノンは ヒドロキノンのほぼ $1 / 2$ の分解能を持っていた。これら の物質のビタミン $\mathrm{B}_{1}$ 分解力の差は, 一般に抗酸化力の 増大にあずかると考学られるフェノール核に導入された アルキル基に関連するもので，その導入によりビタミン $\mathrm{B}_{1}$ 分解作用が低下する。

表-3 NDGA および関連化合物のビタミン $\mathrm{B}_{1}$ 分解力

\begin{tabular}{|c|c|c|c|c|}
\hline 抗 & 酸 & 化 & 剂 & $\begin{array}{l}\text { ビタミン } \mathrm{B}_{1} \\
\text { 分解力 }(0,0)\end{array}$ \\
\hline \multicolumn{4}{|c|}{$\mathrm{N} D \mathrm{G} \mathrm{A}$} & 100 \\
\hline \multicolumn{4}{|c|}{ ヒドロキノン-NDGA } & 98 \\
\hline \multicolumn{4}{|c|}{ ヒドロキノンーヘキセストロール } & 96 \\
\hline \multicolumn{4}{|c|}{ イソアミルヒドロキノン } & 52 \\
\hline \multicolumn{4}{|c|}{ ヒドロキノン } & 98 \\
\hline
\end{tabular}

これらの抗酸化剂の抗酸化力は等濃度ではほとえど

等しいとみてよい。

また BHA，ビタミン $\mathrm{K}_{5}$, ゴシポール，ジイソオイゲ ノールについてビタミン $\mathrm{B}_{1}$ 分解能を試験したところ ${ }^{17)}$, BHA は抗酸化力が強く等濃度でヒドロキノンとひっ敵 する力を持っているがビタミン $\mathrm{B}_{1}$ 分解力は非常に弱 い。抗酸化力では BHA のつぎに位するゴシポール，ビ タミン $\mathrm{K}_{5}$ はビタミン $\mathrm{B}_{1}$ 分解力では $\mathrm{BHA}$ よりも強い。 また抗酸化力の最す弱いジイソオイゲノールがビタミン $\mathrm{B}_{1}$ 分解力が非常に強力であった。この 4 試料をみると ビタミン $\mathrm{B}_{1}$ 分解力と抗酸化力は相反していた。

$\mathrm{BHA}$ が抗酸化力が強くビタミン $\mathrm{B}_{1}$ 分解力の弱いの はフェノール水酸基の一つがメトキシとなり核にアルキ ル基が導入されているためで，NDGA と同様に説明さ れる。ビタミン $\mathrm{K}_{5}$, ゴシポール, ジイソオイゲノール も同様の理由から説明できる。

な招 BHT についても実験を行ったが溶解性が低いた め測定できなかった。

抗酸化剂の利用に当って，この点留意せねばならぬす のと考える。

\section{4. 抗酸化剂の毒性}


表-4 体

重表

（体重の単位 $\mathrm{g}$ )

\begin{tabular}{|c|c|c|c|c|c|c|c|c|c|c|}
\hline \multirow{4}{*}{ 試 } & \multirow{4}{*}{$\begin{array}{l}\text { 衣 } \\
\text { ズ } \\
\vdots \\
\text { 番 } \\
n_{j}^{\prime \prime j}\end{array}$} & \multirow{4}{*}{ 性 } & \multirow{2}{*}{\multicolumn{4}{|c|}{ 試 }} & \multicolumn{4}{|c|}{ (mg/day) } \\
\hline & & & & & & & \multicolumn{2}{|c|}{5} & 10 & 20 \\
\hline & & & \multicolumn{4}{|c|}{ 飼 } & 日 & & & \\
\hline & & & 開始 & 5 & 12 & 15 & 20 & 25 & 30 & 35 \\
\hline \multirow{5}{*}{$\begin{array}{l}\text { Antioxidant } \\
2246\end{array}$} & 1 & 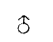 & 34 & 39 & 56 & 69 & 79 & 97 & 106 & 105 \\
\hline & 2 & 우 & 53 & 70 & 83 & 87 & 89.5 & 100 & 101.5 & 104 \\
\hline & 3 & $\hat{\delta}$ & 34.5 & 50 & 66 & 81 & 94 & 113 & 123 & 125 \\
\hline & 4 & 운 & 51 & 75 & 89.5 & 103 & 108 & 125 & 136 & 138 \\
\hline & 平均 & & 43.1 & 58.5 & 73.6 & 85.0 & 92.6 & 108.8 & 116.6 & 118.0 \\
\hline \multirow{5}{*}{ NDGA } & 5 & $\hat{o}$ & 35 & 47.5 & 58 & 68 & 77 & 91 & 102.5 & 108 \\
\hline & 6 & q & 36.5 & 42.5 & 56 & 67 & 76 & $70^{*}$ & & \\
\hline & 7 & 5 & 34.5 & 42.5 & 56 & 66 & 74 & 86.5 & 75.5 & 78 \\
\hline & 8 & 우 & 51 & 69 & 78 & 85.5 & 91.5 & 109 & 118.5 & 112 \\
\hline & 雨均 & & 40.2 & 53.0 & 64.0 & 73.2 & 80.8 & 95.5 & 98.8 & 99.3 \\
\hline \multirow{5}{*}{ ピロガロール } & 9 & $\hat{s}$ & 36 & 48 & 59.5 & 76 & 84.5 & 96.5 & 99.5 & 100 \\
\hline & 10 & q & 33 & 41 & 59.5 & 68.5 & 73 & 86 & 89 & 86 \\
\hline & 11 & 5 & 35 & 50 & 64 & 78 & 74 & 80 & 86 & 89 \\
\hline & 12 & $\hat{s}$ & 27 & 39 & 50 & 51 & 58.5 & 64 & 62 & 64 \\
\hline & 平均 & & 32.8 & 44.5 & 58.3 & 68.4 & 72.5 & 81.6 & 84.1 & 84.8 \\
\hline \multirow{3}{*}{ 無 添 加 } & 13 & $\hat{\delta}$ & 53 & 76 & 88 & 95 & 106 & 119.5 & 130 & 138 \\
\hline & 14 & $q$ & 52 & 61.6 & 75 & 86.5 & 89 & 100.5 & 115 & 124 \\
\hline & 平均 & & 52.5 & 68.8 & 81.5 & 90.8 & 97.5 & 110.0 & 122.5 & 131.0 \\
\hline
\end{tabular}

*21日目死亡, ** No. 6 を除いたものの平均值

抗酸化剂の毒性についてはあまりにも考虑が払われる ことが少ないようである。著者が Antioxidant 2246， NDGA，ピロガロールをネズミに投与してその成長に及 ぼす影響を調べたところ表-4のような成績を得た。この わずかの動物実験によって正確な判定は下せないが，毒 性のあることは十分理解できるはずであるから使用垱 ってはその種類と使用量に注意せねばならぬ

\section{II. カロチン, その他のビタミン}

カロチンについてはビタミン A と全く同様とみてよ い。これの防止はビタミンAに準じて行えばよいわけで ある。

ビタミンDは常温で空気により酸化されるが，これに ついては詳細な研究がなく不活性ガスを用いて酸化を防 止することが行われている程度である。しかし最近トコ フェロール添加により十分防止ができることが報告され ているから，その利用を考えるべきである。

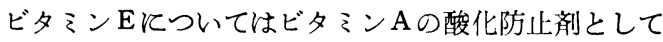
の研究が多く，それ自体の酸化防止についてはあまり考 えられていない。しかしビタミン $\mathrm{E} の$ 酸化物はその生理 効果を失い，また有毒な作用を生ずることも考えられる
ので，その他の抗酸化檦の利用を考学るべきである。ま

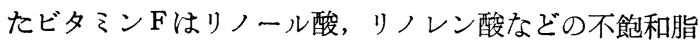
肪酸であるから当然自動酸化をするから，これの防止は 抗酸化剤の添加により行われるわけであるが，油脂中で はトコフェロール，セザモール，その他の天然抗酸化性 物質がこれの酸化を防止している。

\section{III. 結 び}

ビタミン $\mathrm{A}$ ，カロチン，ビタミン $\mathrm{D}, \mathrm{E}, \mathrm{F}$ などは常 温で空気酸化を受けて次第にその効果を失うばかりでな く，毒性の強い分解生成物を生じることもあるので，こ れらの酸化防止は重要な問題であり，これの防止とは種 々の抗酸化剤が使用されている。

抗酸化剂の使用に当ってはその目的によって, それに 適した強力なものを選ぶのはもちろんであるが，そのほ かとそれ自体の毒性，ビタミン $\mathrm{B}_{1}$ 亿対する反応性とつ いても十分考虑が払われねばならない。

(昭和 33 年 4 月 1 日受理)

文 献

1) Kurth, Chen, J. Am. Oil Chemists' Soc., 28, 
433 (1951)

2) 勝井, ビタミン, 6, 69 (1953); 勝井, 飯島, ビ タミン, 9, 19 (1955)

3) 勝井, ビタミン, 10, 58 (1956)

4) Bickoff, J. Am. Oil Chemists' Soc., 28, 65 (1951), Bickoff et al., J. Am. Oil Chemists' Soc., 29, 51, 445 (1952)

5) 桜井, 田辺, 薬学, 1, 88 (1947)

6) 小川, 太幡, 私信

7) 河分, et al., 薬学, 72, 553 (1952); 75, 275 (1955)
8) 勝井, ビタミン, 6, 910, 923 (1953)

9) 勝井, 久川, ビタミン, 4, 422 (1951)

10) 勝井, 久川, 坟本, ビタミン, 7,962 (1954)

11）勝井，深野，ビタミン， 7,966 (1954)

12) 勝那, ビタミン, 6, 69 (1953)

13) 勝排, ビタミン，6，71 (1953)

14）長谷川，ビタミン， 8, 415，421 (1955)

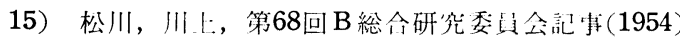

16）川上, ビタミン, 7, 1069 (1954)

17) 勝茾, ビタミン, 12, 515 (1957)

\section{セッケンの 変 敗 \\ 野 中正夫}

\section{Rancidity of Soap}

\section{Masao NonAKA}

セッケンの変敗は, 不飽和油脂を原料とする繊維セッ ケンでは，古くから注意をひいていたが1)，一般とは研 究されることが少なかった。しかし，戦後の油脂事情か ら原料面に相当制限を受け，七ッケンの変敗に大きな関 心が払れるようになった。そして次第に変敗防止が実用 化されてきて，わが国でもセッケンの抗酸化戍（たとえ ば Sopanox, EDTA のような）の製造や輸入が，ある 程度行われるようとなった。

セッケンの変敗については, 先に富山が他誌 ${ }^{4)}$ 飞詳し く述べているので, 筆者は研究業績を紹介するより, む しろ実際製造上の見地から少し述べることにしたい。

\section{セッケンの変敗とは}

セッケンの変敗ということは, セッケンの表面に特異 な性質の変化の起ることである。その第一の徴候は, 二 オイの変化である。さらに変敗が進むと着色してくる。 セッケンのニオイの初めの変化は新鮮なニオイの消失で ある。それが進むと,セッケンの全表面次第に，あるい は急治拡がり, 色が変ってきて, 黄色のハン点が生じ, あるいは全面暗色となり発汗することもある。このよう 飞変敗により外観がそこなわれ，不快な臭気が生じて， 商品価值を低下させるので, セッケンの品質保持上重要 な問題である。強く変敗したセッケンを試験すると,ア ルカリと結合していない酸性物質を著量飞含しでいる。 したがつてセッケンの変敗は, 酸性物質の生成に関連す ることがよく知られている。すなわち酸敗により起るも のと考觉らる。

酸性物質の生成はつぎのように起るすのとされてい
る。

a ）未ケン化脂肪の扠水分解

b ）不館和化合物の酸化

c) 微生物の生物的過程

c)飞ついてはセッケンの変敗に関してあまりよく研究 されていないが，他の二者は既に古くから研究の対象と なっていて，これらが互い強く影響し合い，七ッケン の急激な変敗の因をなしている。

油脂の酸敗については, その反応機構も数多くの研究 が行われたが，セッケンについては未だ多く研究されて いない。この二つの場合油脂とセッケンとは, 酸敗の原 因となる化合物が同じであるから, 油脂に行われた研究 結果が，大部分セッケンにも適用できるるのと考党られ ている。

セッケン中の遊晟脂肪が長い間と水とアルカリの作用 飞より加水分解されて脂肪酸を生成し, 脂肪酸は油脂, セッケンより酸化されやすく, 急激に酸敗してセッケン を変敗導く。

セッケン中の不飽和化合物として考兄られるのは, 脂 肪酸, 未ケン化物質, 香料, 過脂肪凨などである。これ らの物質に上る酸素吸収は, その条件によっては急激な こともあり, 緩慢なこともある。不飽和脂肪酸の酸化過 程については, 多くの研究で明らかにされていて, オキ シ酸が生成されることはよく知られているが，原料油脂 中のオキシ酸は普通のセッケンでは塩析操作で廃液中に 移行するのでごく少量しか存在しない。しかし，セッケ ン製品となってからは，脂肪の場合と同様の過程を経る ものと考兄られる。また, 天然の油脂には天然の抗酸化 